\title{
Smoking and premature mortality: reflections on the contributions of Sir Richard Doll
}

Cir William Richard Shaboe $\checkmark$ Doll, one of the world's most accomplished epidemiologists, died on July 24, 2005, in Oxford, aged 92 years. Sir Richard had a long and distinguished career, first at the United Kingdom's Medical Research Council in London and then at the University of Oxford.

In the 1930s, routine mortality statistics from the UK and the United States showed a marked increase in lung cancer deaths among men, and no one knew why. The Medical Research Council asked Sir Richard and Sir Austin Bradford Hill to investigate the likely causes: exhaust fumes from automobiles and smoking.

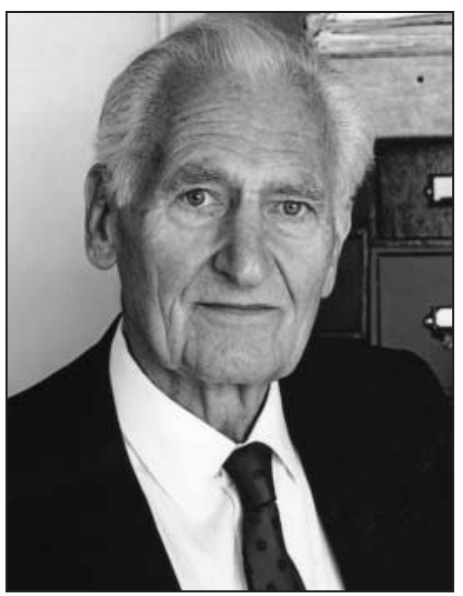

Sir Richard Doll, a leading figure in tobacco control research, died on July 24, 2005.

Sir Richard and Sir Austin asked male patients in London hospitals with lung cancer or other diseases a wide range of questions to identify a possible link. They included questions about smoking patterns. The results were striking: almost all of the men with lung cancer smoked whereas far fewer of those with other diseases did. The findings were published in a now-classic paper in the British Medical fournal in $1950 .^{1}$

Sir Richard was not the first to discover the link between smoking and disease, but he was surely the most influential scientist in tobacco research. He became an icon of tobacco control, lecturing widely on the hazards of tobacco. He inspired 2 generations of tobaccocontrol experts, epidemiologists and clinicians.

Sir Richard knew that opposition from the tobacco industry to his findings would be fierce. Fortunately, he was by nature obsessed with documenting evidence meticulously, to very exacting standards. With Sir Austin, he established a prospective study of 40000 UK doctors; they were interviewed about their smoking patterns and followed until they died. By 1964 this study had revealed that smoking posed a substantial risk of developing lung cancer and other diseases. Twenty-year, 40-year and 50-year follow-up studies were published in 1976, 1994 and $2004,{ }^{2}$ respectively. The results were clear: men (most of the UK doctors enrolled were male) who smoked throughout life died in excess not only from lung cancer but also from other cancers, cardiovascular diseases and respiratory diseases. Moreover, the hazards became more extreme with prolonged smoking: male smokers who took up the addiction during the peak period of cigarette consumption just before World War II lost fully 10 years of life compared with nonsmokers. ${ }^{2}$ The use of doctors was ingenious. Once they realized, as Sir Richard joked, that smoking killed not only patients but doctors, the UK medical establishment became a leading force for tobacco control.

Sir Richard knew that simply documenting the risks of smoking was not enough. Indeed, much of his later work with Sir Richard Peto focused on documenting the benefits of cessation. The 40- and 50-year fol- low-up studies of UK doctors showed definitively that smokers who quit before the onset of disease avoid much of the risk of continued smoking. The benefits of quitting were largest in those who quit before middle age (between ages 25 and 34 years) but were still significant in those who quit later (between ages 45 and 54 years).

Irrefutable evidence such as that produced by Sir Richard and his colleagues spurred the development of a range of tobacco-control measures, the most effective of which is higher tobacco taxes. ${ }^{3}$ The reliable quantification of tobacco hazards in Western populations has played a direct role in the remarkable reduction in smoking rates and smoking-related death rates in those countries.

Over the last 10-15 years, tobacco-related mortality has fallen in most Western populations, particularly among men. In the UK the number of tobacco-related deaths has fallen by more than half in the past 3 decades in people aged 35-69 years, and smoking prevalence has fallen from about $80 \%$ in the 1950 s to about $25 \%$ today. Dramatic declines in lung cancer death rates among men are common: Canada and Poland provide but 2 examples. ${ }^{4}$

Despite this progress, smoking is still a leading killer of adults. Tobacco use is estimated to kill nearly 5 million people worldwide annually, accounting for 1 in 5 deaths among men over age 30 years and 1 in 20 deaths among women over age 30 years.

It is still too early to measure the impact of Sir Richard's focus on cessation in his later years. Today, far too many tobacco control programs (and politicians) focus on children; most of the people who will die from tobacco-related causes over the next half-century are today's 
adult smokers. ${ }^{3}$ The clear priority is to get them to quit. It is worth remembering the story about a person who heard Sir Richard speak in London in the 1960s and claimed loudly, "This is great; all we have to do is to get kids not to start smoking, and the epidemic will end." It turns out the person worked for the tobacco industry.

A key lesson from Sir Richard's work is the need for direct measurement of tobacco epidemics, which vary by time, place, region and even socioeconomic group. If current smoking patterns continue, tobacco-related deaths will rise to 10 million annually by 2030 , with most of these in developing countries. It is likely that 1 billion people will die of tobacco-related causes in the 21st century, again mostly in the developing world. In contrast, most of the 100 million tobacco-related deaths in the 20th century were in industrialized countries. Particularly for large populations such as those in China, India, Indonesia, Brazil, Russia and Nigeria, direct evidence is needed on the variable hazards of smoking, the benefits of cessation and the response to control programs. Indeed, the results from early work in India are surprising: smoking accounts for half of the tuberculosis deaths in India and contributes to increased transmission of the infection. ${ }^{5}$

For most scientists, making a fraction of Sir Richard's contribution to our understanding of the links between smoking and disease would constitute a stellar career. But Sir Richard also excelled at research on oral contraceptives, radon and gastric diseases. He established methods of cancer research, including cancer registries worldwide, and helped launch the International Agency for Research on Cancer. $\mathrm{He}$ is remembered by colleagues for clear thinking and even sharper writing. For any serious student of epidemiology, his articles remain essential reading.

Sir Richard was nominated several times for a Nobel Prize and was knighted in 1971. One of his last public acts was to open the new Richard Doll building, which now houses the epidemiological and clinical trials study groups at the University of Oxford.
Prabhat Jha

Canada Research Chair in Health and Development

Public Health Sciences

University of Toronto

Centre for Global Health Research

St. Michael's Hospital

Toronto, Ont.

Witold A. Zatonski

Cancer Epidemiology and Prevention

Division

Cancer Centre and Institute

of Oncology

Marie Sklodowska-Curie Memorial

Cancer Center

Warsaw, Poland

\section{References}

1. Doll R, Hill AB. Smoking and carcinoma of the lung. BM7 1950;2(4682): 739-48.

2. Doll R, Peto R, Boreham J, Sutherland I. Mortality in relation to smoking: 50 years' observations on male British doctors. BM7 2004;328(7455):1519.

3. Jha P, Chaloupka FJ. The economics of global tobacco control. BMF 2000; 321(7257):358-61.

4. Peto R, Lopez AD, Boreham J, Thun $\mathrm{M}$, Heath CJ. Mortality from smoking in developed countries 1950-2000: indirect estimates from national vital statistics. 2nd ed. Oxford: MRC/Cancer Research UK/BHF Clinical Trial Service Unit; 2004. Available: www.ctsu.ox.ac.uk/ tobacco/ (accessed 3 Aug 2005).

5. Gajalakshmi V, Peto R, Kanaka TS, Jha P. Smoking and mortality from tuberculosis and other diseases in India: retrospective study of 43000 adult male deaths and 35000 controls. Lancet 2003;362(9383):507-15.

\section{Please, reader, can you spare some time?}

Our annual CMAJ readership survey begins September 7. By telling us a little about who you are and what you think of $C M A J$, you'll help us pave our way to an even better journal. For 2 weeks, we'll be asking you to take the survey route on one of your visits to the journal online. We hope you'll go along with the detour and help us stay on track.

\section{Chers lecteurs et lectrices, pourriez-vous nous accorder un moment?}

Le sondage annuel auprès des lecteurs du JAMC débute le 7 septembre. En nous parlant un peu de vous et de ce que vous pensez du $J A M C$, vous nous aiderez à améliorer encore le journal. Pendant deux semaines, lorsque vous rendrez visite au journal électronique, nous vous demanderons de passer une fois par la page du sondage. Nous espérons que vous accepterez de faire ce détour qui contribuera à nous garder sur la bonne voie. 